\title{
THE HEBREW MANUSCRIPT FROM "THE NEW FIND" IN THE MONASTERY OF ST. CATHERINE \\ A Jewish Machzor
}

\author{
Bo IsAKsSON \\ Uppsala

A B S T RACT As a library of manuscripts from the ancient Middle East, the Monastery of St. Catherine in Sinai is second to none except that of the Vatican. In 1975, a new find of manuscripts was made in the monastery, including one Hebrew paper codex. In 1996 I visited the monastery for an examination of the manuscript, which turned out to be a Jewish Machzor. The script type is Sephardic and the watermarks indicate a date in the 16 th century. The size of the codex is $157 \times 110 \mathrm{~mm}$ and its 144 folios contain 279 pages with Hebrew or Aramaic texts. The codex contains a Jewish liturgy to Rosh Hashana and Jom Kippur together with I04 piyyutim, inserted in extenso. 21 of these are written by Moshe ibn Ezra from Granada, and at least one of the piyyutim - "God, save me by thy name" - is previously unknown.

In the year 198r His Eminence Damianos, the Archbishop of the Monastery of St. Catherine in Sinai, announced officially a new find of manuscripts in the monastery. The announcement was made at the I6th International Congress of Byzantinists in Vienna. Among the manuscripts mentioned by the archbishop was a Hebrew codex, without any further specifications. This new find of completely unknown manuscripts was made already in 1975 and came to be called "The new find". 
I visited the Monastery during a trip to Egypt 1994 and received permission by the Archbishop to see the library of manuscripts. At the same time a document photographer from Greece worked in the Monastery and while showing me the codices of the library he also informed me about the new find in 1975 .

When I came home I wrote to Professor Panayotis Nicolopoulos, the director of the National Library of Greece in Athens. He functions as a scientific consultant for the Monastery in questions regarding the Library. Obviously the Greek manuscripts have been in the focus of interest and Nicolopoulos did not know anything further about the Hebrew manuscript. He adviced me to write directly to the Archbishop in the Monastery about the newly found Hebrew manuscript and in spring 1996 he answered me. It turned out that Damianos had no further data about the manuscript except its language and that it was safely stored within the Monastery. He invited me to visit the monastery for a first examination, which I performed one week in May 1996.

\section{BACKGROUND}

Before I venture into a description of the codex it is pertinent to give a short background information about the Monastery of St. Catherine. For further details I refer to my article "The Monastery of St. Catherine and the New Find" in the Festschrift to Ebbe E. Knudsen 1997.

Despite its ecclesiastical character, the Monastery of St. Catherine is an important scientific institution in the field of Semitic philology. As a library of manuscripts from the ancient Middle East it is second to none except that of the Vatican.

Since its foundation some time in the middle of the 6 th century, ${ }^{1}$ the Monastery of St. Catherine, situated in the southern part of the Sinai peninsular, has been lucky enough to enjoy an unbroken tradition. It has never been robbed, never plundered, and this is partly due to its isolated position in the southern part of the Sinai Peninsula, partly because it has been respected by both Christians and Muslims. 
Before 1975 the Monastery possessed 3329 manuscripts in 12 languages: ${ }^{2}$

- 23 I9 Greek MSS. ${ }^{3}$

- 696 Arabic (all Christian, mostly liturgical and patristic) MSS, of which 36 were missing in 1949, 59 actually are printed books, and one is in Persian, which means the Arabic MSS are 600 in number. ${ }^{4}$

- 266 Syriac MSS. ${ }^{5}$

- 3 Christian Palestinian Aramaic MSS.

- 6 Ethiopic MSS.

- I Persian MS, in earlier lists mistakenly held as Arabic. ${ }^{6}$

- I Latin MS, a Ioth century Psalter.

- 86 Georgian MSS. ${ }^{7}$

- I Armenian MSS.

- I Coptic MSS.

- 42 Slavonic MSS. ${ }^{8}$

- r Polish MS. ${ }^{9}$

The age of the MSS varies from the $4^{\text {th }}$ Century to modern times. The most famous is Codex Sinaiticus, dated to the middle of the $4^{\text {th }}$ century and one of the most important text witnesses to the Septuagint. The greater part of this manuscript was discovered in I844 by the German scholar $\mathrm{K}$. Tischendorff and subsequently in I859 during obscure circumstances transfered by him to Russia and presented to the Tsar. Later it was sold to the British Museum. ${ }^{10}$ Happily, in the new find 1975, a few new pages of Codex Sinaiticus were discovered, complementing missing pages in the British $\mathrm{Mu}-$ seum codex. The memory of this theft and other examples of improper behaviour by scholars has caused the Fathers of the Monastery to exercise extreme cautiousness in showing their treasures to foreigners. Visitors are normally not allowed to see the library at all. Only with special permission from the Abbot, who bears the title Archbishop, it is possible for a scholar to examine a manuscript, and in such a case only in the presence of one of the Fathers.

In the New find in 1975 a store room of ancient manuscripts was discovered at St. Catherine's Monastery, in the northern Justinian wall. At some time in the history of the Monastery this storeroom 
had been blocked up and forgotten. The room contained more than 70 boxes of discarded fragments. ${ }^{11}$ During repairs in an old section of the northern Justinian wall, building workers demolished a wall and unexpectedly discovered a little room which appeared to be a storeroom full of chests. When the chests were opened they turned out to be filled with papyri, parchment manuscripts, and very old written documents of all kinds. ${ }^{12}$ Some of the finds lay right in the dust, detached leaves, torn fragments, rollers of scrolls, bindings unstuck from their codex, and so on..$^{13}$ This state of decay also characterizes the Hebrew manuscript.

A third of the New find turned out to be complete codices and there were no less than I2O scrolls. The dates range from the $4^{\text {th }}$ to the x8th century. Most sensationally, there were also some leaves in the store-room of the already mentioned Codex Sinaiticus, and also some leaves of a 9 th century manuscript with the first five books of the Iliad. The new find also turned out to contain a large number of papyri in addition to the old collection of papyri containing 42 text and I2 fragments. It added once in a while 83 texts and to fragments. Most of these new papyri are in Greek and Latin, some as early as the 6th century, contemporary with the foundation of the Monastery. ${ }^{14}$ The find also contained II 48 handwritten codices, of which 836 were Greek manuscripts and 155 Arabic MSS. In addition there were some Syriac, Slavonic, and Armenian MSS, 2 Latin MSS, 2 Ethiopian, and I Hebrew (!). Most of the manuscripts are Christian texts, biblical texts, liturgical texts, prayer books, and so on. ${ }^{15}$ Only the Hebrew manuscript was non-Christian. It is the only Hebrew manuscript in the Monastery and the only one with roots in the Jewish Synagogue Service.

\section{The Codex}

When I visited the Monastery in 1996, the Hebrew MS I encountered for the first time turned out to be a medieval paper codex with 144 folio leaves. 279 pages contained Hebrew or Aramaic texts. During my week in the Monastery I performed a pagination of the 
codex. The script type is Sephardic of the semi-cursive (Mashait) mode. This means that the manuscript has probably been written in Spain or the Maghrib, or possibly in southern Italy. A check in Birnbaum, The Hebrew Scripts, ${ }^{16}$ which I brought with me, indicated that the script is very similar to that in a Hebrew manuscript in Toledo from 1366 (Birnbaum, no. 25I). ${ }^{17}$ However, the watermarks indicate a later dating. I have identified most of the watermarks in the paper with the help of the standard work of Briquet, Les filigranes; dictionnaire historique des marques du papier (Geneva, 1907). The watermarks indicate a date rather in the I6th century. I am not an expert of medieval codices nor of early paper production, so the dating is indeed preliminary. The codex is damaged by mice or insects, ${ }^{18}$ but the preserved text is otherwise generally readable, often beautiful. There is no title page, nor a colophon which could indicate a date and place of origin. The text on the first page begins abruptly. This together with the fact that the binding is in a bad state makes it likely that the codex once contained more leaves. The size of the codex is $157 \mathrm{x}$ Iro $\mathrm{mm}(\mathrm{H} \times \mathrm{W})$. The first 45 folio are damaged by a hole in the middle of the page. Mice and insects have also damaged a large part of text close to the inner margin. The latter damage has affected nearly all folios. In addition there is a hole at the outer margin affecting the last Ir folio. The outer margin is usually about $20 \mathrm{~mm}$, the inner margin about $15 \mathrm{~mm}$, the top margin $18 \mathrm{~mm}$, and the bottom margin about $36 \mathrm{~mm}$.

The quality of the script varies throughout the MS. A folio page generally contains I5-I6 lines, but there are pages with 25 lines and considerably smaller script. We may compare the script in the codex with the aforementioned no. 25I of Sephardic script in Birnbaum's standard work.

Birnbaum no. 25I:

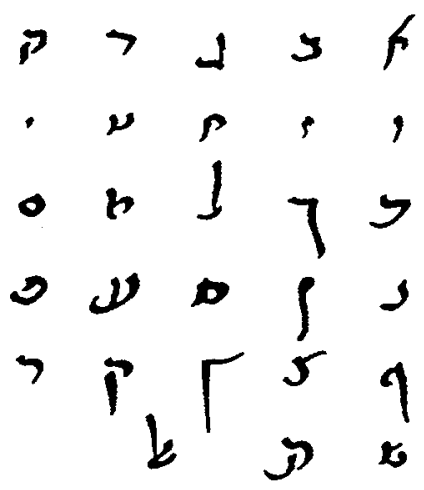


Note the characteristic form of the Sephardic $x$. Other characteristics are the forms of the letters $w, ה$ and $\lambda$. It is easy for an unexperienced reader to confuse $ה$ with $p$. A comparison with Birnbaum's sample letters indicates that the script of the codex deviates in a few points. The short upper slanting in $\mathrm{x}$ is shorter and less marked, the final nun has an upper stroke to the left and not to the right, and in $w$ the slanting stroke begins higher up. and $د$ are easily confused. Note also the ligature of אל. The earliest example of such a ligature is found in a MS with square script in Egypt from the 8th century. ${ }^{19}$ The emergence of this ligature is due to the writing of Arabic with Hebrew characters, a habit that began among Jews in Spain after the Muslim conquest in al-Andalus. In order to spare time and space the Jews began to write the Arabic definite article 'al-as a combination of the Hebrew letters alef and lamed $(\mho)$. The habit of using such a ligature was never adopted by the Muslims. Later on, the ligature came to be used in all Arabic words containing the sequence $S$ not only for the Arabic definite article. Finally, the ligature came to be used also in Hebrew texts as in this codex.

As far as dating is concerned the script only is an unreliable indicator. Watermarks in the paper indicate the producer of the paper and thus an identified watermark offers a first possible date of the manuscript. During my stay in the Monastery I examined the watermarks and tried to copy them by free hand. Unfortunately I had no special equipment for reproducing the watermarks, like beta-radiography. This is a task that still waits to be done. The number of different watermarks at least indicates that the codex was produced of paper from several different producers. Even the varying quality of the paper indicates this. One of the most common watermarks is similar to Briquet nr. 3465 , viz. a hat. This watermark is dated to 1536 and a paper producer in Italy (Venice or Bologna). It should be pointed out that no watermark is complete on one and the same folio since the original sheet was folded several times before binding of the codex. Another common watermark represents a hand with fingers stretched upwards towards a flower, like Briquet nr. 10718, the paper of which is dated to about $1500 .^{20}$ 
Parts of this hand are found on folios $74,75,87,,^{21} 94,9598,99$, IOO, II4. Another common watermark is an anchor on a coat of arms, as no. 469 in Briquet, dated to 1512 , a paper produced in Bologna. A dating to the I6th century has been confirmed to me by one of the world's leading experts on Medieval Hebrew manuscripts, Professor Malachi Beit-Arié in Jerusalem.

The binding of the codex has been performed by folding of larger sheets of paper, sewing and glueing the folded sheets together in the back. The number of folio for each sheet is puzzling. I examined the binding carefully and arrived at the following statistics:

$\begin{array}{lll}\text { Sheet nr. } & \text { Number of folios } & \text { Pages } \\ \mathrm{I} & 23 & \mathrm{Ir}-23 \mathrm{~V} \\ 2 & 22 & 24 \mathrm{r}-45 \mathrm{~V} \\ 3 & 17 & 46 \mathrm{r}-62 \mathrm{~V} \\ 4 & 2 \mathrm{r} & 63 \mathrm{r}-83 \mathrm{~V} \\ 5 & 18 & 84 \mathrm{r}-\mathrm{IOIV} \\ 6 & 20 & \text { IO2I-I2IV } \\ 7 & 23 & \text { I22r-I44V }\end{array}$

I am not a codicologist and cannot presently explain these numbers. It might be that the codex has been produced from discarded paper material. This would help explain why we find uneven number of leaves in some sheets. The technique of folding larger sheets to quires should logically produce quires with an even number of folios. As already stated, the codex has no title page, no preface, and no colophon. There are no covers. The binding in the back is in a bad state of preservation. The folios are often very loose.

\section{The content of the Codex}

The codex contains a Jewish, probably Sephardic liturgy to Rosh Hashana and Jom Kippur. In this seder piyyutim are inserted in 
extenso. Among the authors of the piyyutim the dominating figure is Moshe ibn Ezra (also known as Abu Hārūn), a poet from Granada in Andalusia, who lived about I055-1r35. Other known authors of piyyutim in the codex are Isaac ben Levi ibn Mar Saul, Jehuda Halevi, Abraham ibn Ezra, David ibn Bekoda, Hay Gaon (d. I038), Solomon ibn Gabirol, Joseph ben Avitur, Yose ben Yose, Isaac ben Judah ibn Ghayyat, Isaac ibn Israel, Jehuda ibn Abbas, Israel Najara. I have so far identified 2I pious poems or piyyutim by Moshe ibn Ezra. There are more than 83 other piyyutim, which makes the codex a considerable collection of Medieval Jewish religious poetry. At least one of the piyyutim is previously unknown, ${ }^{22}$ "God, save me by thy name", 9v8 - Iors:.23

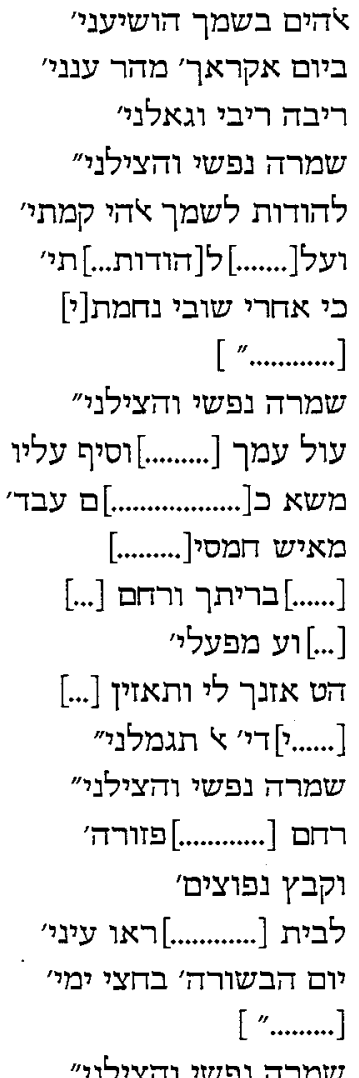


The core of the text in the codex is the Jewish liturgy of the two festivals that are commonly called Yâmin nōră $\bar{z} m$. The text contains a lot of additions that seem to be relatively late compared with the critical text of the Jewish siddur found in e.g. Goldschmidt's edition (1970), but also compared with the early Seder Amram Gaon, edited by David Hedegård (1951), Tryggve Kronholm (1974) and Goldschmidt (I970). The liturgy exhibits Sephardic characteristics like the words underlined from 2 Ir8-II:

$$
\begin{aligned}
& { }^{24} 8 \\
& 9 \\
& \text { Io }
\end{aligned}
$$

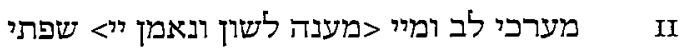

\section{Notes}

I. Late in the life of emperor Justinianus, between $548-565$, cf. Galey (1980), I2 f.

2. The numbers that follow are taken from Kamil (1970), unless otherwise stated.

3. Kamil (1970), 60; Clark (1952), VII, mentions 229r.

4. Clark (1952), VII. Kamil (1970), 7, 52, numbers 60I items.

5. Clark (1952), VIII, numbers 257. Kamil (1970), 149, 160, says 266. Manafis (I990), 393 note I, adduces 270 Syriac MSS.

6. Kamil (1970), I45. From I470 AD

7. Clark (1952), VIII. Kamil (1970), 56.

8. Thus Kamil (1970), 147. Clark (1952), VII, says 40, but Kamil discovered some new items.

9. Kamil (1970), I46. From the I8th century.

ro. Catalog number B. Mus. Add. 43725 .

II. Including eight more pages of Codex Sinaiticus, the famous Bible manuscript in Greek, which proves that from the time of the Monastery's founding books were given to it antedating the time of Justinian. Charlesworth (198I).

I2. Charlesworth (198I), I.

I3. Manafis (1990), 354 .

14. Manafis (1990), 356 .

I5. Damianos (1982). I am indebred to Professor Lennart Rydén, Uppsala, who kindly translated the document to me.

16. Birnbaum (1971), 267 ff., Birnbaum (r954-57), no. 25I. 
I7. Birnbaum (1954-1971), no. 251 .

I8. This is the supposition of the Fathers in the Monastery.

I9. Birnbaum (1971), 225.

20. No. 10718 (I499-I500).

2I. As e.g. Briquet no. 10709 (I478), paper produced in Rhodes.

22. Confirmed by an expert of Jewish religious poetry in Jerusalem, Dr. Nahum Weisenstern. I thank Prof. Malachi Beit-Arié for this report.

23. Folio page 9 verso line 8 to page to recto line 5. The codex has been paginated by me. Translation of the first line: "God, save me by thy name! When I cry to you, answer me quickly. Defend me and redeem me. Keep my soul and save me, that I may praise your name, o God that keeps me standing. [...] for after my repentence I have got consolation. [...] Keep my soul and save me."

24. SRA (Goldschmidt), I42, remarks that אוחילה לאל אחלה פניו is read in Sefarad.

\section{RefERENCES}

Atiya, Aziz S. The Arabic Manuscripts of Mount Sinai. A Hand List of the Arabic Documents and Scrolls Microfilmed at the Library of the Monastery of St. Catherine Mount Sinai in 1954. Baltimore: Johns Hopkins Press, 1955. —. "The Arabic Treasures of the Convent of Mount Sinai." The Egyptian Society of Historical Studies 2 (1952): 5-26.

- Catalogue Raisonné of the Mount Sinai Manuscripts. Translated by J. N. Youssef. Alexandria: Al-Maaref Establishment, I970.

Beit-Arié, Malachi. Hebrew Codicology: Tentative Typology of Technical Practices Employed in Hebrew Dated Medieval Manuscripts. $2 \mathrm{~d}$ ed. Jerusalem, i98I.

—_. "Hebrew Script in Spain: Development, Offshoots and Vicissitudes." In Moreshet Sepharad. The Sephardi Legacy, edited by H. Beinart. 282-317. Jerusalem: Magnes, I992.

- The Makings of the Medieval Hebrew Book. Studies in Palaeography and Codicology. Jerusalem: Magnes Press, I993.

Birnbaum, Solomon A. The Hebrew Scripts. Part I-II. London: Palaeographia, I954-1957, 1971.

Briquet, Charles Moise. Les filigranes; dictionnaire historique des marques du papier dès leur apparition vers 2282 jusqu'en 1600 . Edited by A. Stevenson. Vol. I-IV. Geneva, 1907. A facsimile of the 1907 edition with supplementary material contributed by a number of scholars. Amsterdam: The Paper Publications Society (Labarre Foundation), 1968.

Charlesworth, James Hamilton. "The Manuscripts of St. Catherine's Monastery." Biblical Archaeologist 43, no. I (I980): 26-34. A slightly changed version of this paper has been reprinted in Charlesworth and 
Zervos, The New Discoveries in St. Catherine's Monastery, Winona Lake, I981, pp. 9-13.

Charlesworth, James Hamilton and George Themelis Zervos. The New Discoveries in St. Catherine's Monastery: A Preliminary Report on the Manuscripts. American Schools of Oriental Research, Monograph Series, 3. Winona Lake, In: American Schools of Oriental Research/ Eisenbrauns, 198x.

Clark, Kenneth W. Checklist of Manuscripts in St. Catherine Monastery Mount Sinai. Washington: Library of Congress, I952.

- "Exploring the Manuscripts of Sinai and Jerusalem." Biblical Archaeologist I6 (1953): 22-43.

- "The Microfilming Projects at Mount Sinai and Jerusalem." The Library of Congress Quarterly Journal of Current Acquisitions 8, no. 3 (I951): 6-12.

Cross, Frank Moore. "The Development of the Jewish Scripts." In The Bible and the Ancient Near East. Essays in Honor of William Foxwell Albright, edited by G. E. Wright. 133-202. London: Routledge \& Kegan Paul, 196r.

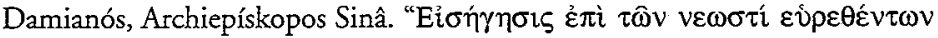

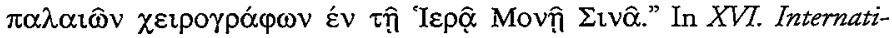
onaler Byzantinistenkongress, Wien, 4.-9. Oktober I98I. Akten, edited by H. Hunger. II/4. IO5-II6. Jahrbuch der Österreichischen Byzantinistik, 32/4. Wien: Verlag der Österreichischen Akademie der Wissenschaften, I 982 .

Davidson, Israel. אוצר השירה יהפיוט (Thesaurus of Mediaeval Hebrew Poetry). 4 vols. New York: Jewish Theological Seminary of America, I924-38.

Elbogen, Ismar. Der jüdische Gottesdienst in seiner geschichtlichen Entwicklung. Frankfurt a. Main r93I. Reprint. Hildesheim: Olms, 1967.

_. Studien zur Geschichte des jüdischen Gottesdienstes. Berlin, I907.

Galey, John. Sinai and the Monastery of St. Catherine. London: Chatto \& Windus, 1980.

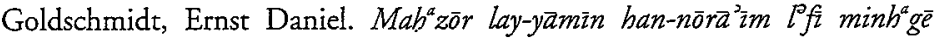

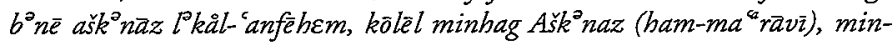
hag Pōlìn, ü-minhag Sar fat $l^{2}$-š- avar (Prayer book for Rosh Hashana and Jom Kippur according to the orders of Jews of Ashkenaz in all their branches: the congregation with the order of West-Germany, the order of Poland and the previous order of France). Vol. I, Rosh Hashana. Vol. 2, Jom Kippur. New York: Leo Baeck Institute, Inc., I970.

-. Seder Rav Amram Gaon. Jerusalem: Mossad Harav Kook, 1971 (=SRA). Hedegård, David. Seder R. Amram Gaon. Hebrew Text with Critical Apparatus, Translation with Notes and Introduction. Part I. Diss. Lund: Lindstedts Universitets-Bokhandel, I95I.

Ibn Esra, Moses. שירי משה בן יעקב אבן עזרא. Edited by C. N. Bialik and J. C. Rabnitzki. Vol: I-2 שירי חול, with commentary. Tel-Aviv: Dvir, 5688 (1928). 
The Collected Liturgical Poetry of Mose Ibn Ezra. Circa I055-60-II35-38 Granada-Toledo, Spain. Edited and annotated by S. Bernstein. Tel-Aviv: Massadah Publ. Co., 5717 (I957).

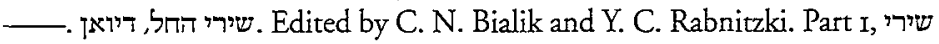
כבוד. Berlin: Schocken, 5688 (r928).

-שירי החל . שי שי Edited by C. Brody. Part I. Berlin: Schocken, 5695 (I935).

Isaksson, Bo. "The Monastery of St. Catherine and the New Find." In Built on Solid Rock. Studies in Honour of Professor Ebbe Egede Knudsen on the Occasion of his 65th Birthday April IIth 1997, edited by E. Wardini. 128140. Instituttet for sammenlignende kulturforskning. Serie B: Skrifter, 98. Oslo: Novus, 1997.

Kamil, Murad. Catalogue of All Manuscripts in the Monastery of Saint Catherine on Mount Sinai. Wiesbaden: Harrassowitz, 1970.

Kronholm, Tryggve. Seder R. Amram Gaon. Text Edition with an Annotated English Translation and Introduction. Part II. Diss. The Order of Sabbath Prayer. Lund: CWK Gleerup, I974.

Manafis, Konstantinos A. (general editor). Sinai. Treasures of the Monastery of Saint Catherine. Translated by G. Cox, S. Gerstel, D. Mouriki, F. Flint, D: Turner, and I. Turner. Athens: Ekdotike Athenon S.A., I990.

Mayerson, Philip. "Codex Sinaiticus: An Historical Observation." Biblical Archaeologist 46, no. I (1983): 54-56.

Meïmáris, Ioánnis E. Katálogos tôn véon arabikôn cheirográfon tês Hierâs Monês Hagías Aikaterines tồ Orous Sinâ. Athens, I985.

Meyer, Marvin W. Review of Secrets of Mount Sinai, by James Bentley. Biblical Archaeologist 52, I (I989): 40-4I.

Reif, Stefan C. Judaism and Hebrew Prayer. New Perspectives on Jewish Liturgical History. Cambridge: Cambridge UP, I993.

Sevcenko, I. "The Early Period of the Sinai Monastery in the Light of Its Inscriptions." Dumbarton Oaks Papers 20 (1966): 255-264. 